\title{
Functions and mechanisms of long noncoding RNAs in lung cancer
}

This article was published in the following Dove Press journal:

OncoTargets and Therapy

20 July 2016

Number of times this article has been viewed

\section{Zhenzi Peng \\ Chunfang Zhang \\ Chaojun Duan}

Institute of Medical Sciences, Key Laboratory of Cancer Proteomics of Chinese Ministry of Health, Xiangya Hospital, Central South University, Changsha, People's Republic of China

\begin{abstract}
Lung cancer is a heterogeneous disease, and there is a lack of adequate biomarkers for diagnosis. Long noncoding RNAs (lncRNAs) are emerging as an important set of molecules because of their roles in various key pathophysiological pathways, including cell growth, apoptosis, and metastasis. We review the current knowledge of the lncRNAs in lung cancer. In-depth analyses of IncRNAs in lung cancer have increased the number of potential effective biomarkers, thus providing options to increase the therapeutic benefit. In this review, we summarize the functions, mechanisms, and regulatory networks of lncRNAs in lung cancer, providing a basis for further research in this field.
\end{abstract}

Keywords: ncRNA, tumorigenesis, biomarker, network, proliferation, apoptosis

\section{Introduction}

Besides small-cell lung cancer, non-small-cell lung cancer (NSCLC) is any type of epithelial lung cancer and accounts for $85 \%$ of all lung cancers. The 5-year survival rate of this heterogeneous disease is $16.6 \%$, and it has only improved slightly in the past few years. ${ }^{1}$ NSCLC can be classified into discrete subclasses according to histological phenotypes, including squamous cell carcinoma (SCC), adenocarcinoma (ADC), and large-cell carcinoma. The most common type of NSCLC is ADC, which is less associated with smoking and chronic inflammation than SCC. ${ }^{2}$ The clinical integration of ADC in terms of predictive biomarker signatures is characterized by positive immunostaining for cytokeratin 7 and TTF1; however, SCC is characterized by positivity of cytokeratin 5, cytokeratin 6 and/or SOX2, and p63. ${ }^{3,4}$ In addition to tissue biopsy for clinical diagnosis, specific gene mutations in tumors have highlighted their usefulness as diagnostic markers and molecular therapy targets. For instance, $E G F R, A L K$, and MET mutations are always found in ADC patients. ${ }^{2}$ However, DDR2, FGFR1, and FGFR2 mutations, as well as mutations in genes in the PI3K signaling pathway, are generally found more frequently in SCC. ${ }^{5}$

\section{Characteristics of IncRNAs}

Noncoding RNAs (ncRNAs) are a superclass of endogenous, non-protein-coding RNA transcripts, many of which have essential functions in various cellular processes. Based on their function, ncRNAs can be classified into two subclasses, namely housekeeper ncRNAs (rRNA, tRNA, snRNA, snoRNA) and the regulated ncRNAs. The regulated ncRNAs can be categorized by length as follows: any ncRNA $<200$ nucleotides (nt) in length is a short ncRNA (siRNA, miRNA, piRNA) and those $>200 \mathrm{nt}$ in length are

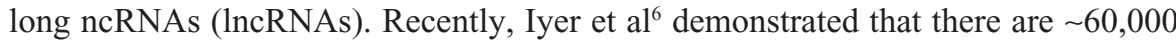
ncRNAs in the human genome, and $>68 \%$ of these are lncRNAs, of which $\sim 80 \%$
Correspondence: Chaojun Duan Institute of Medical Sciences, Key Laboratory of Cancer Proteomics of Chinese Ministry of Health, Xiangya Hospital, Central South University, No 87 Xiangya Road, Changsha 4l0008, Hunan, People's Republic of China

Tel +86 73I 84327069

Fax +8673184327332

Email duancjxy@I26.com 
are not annotated. Approximately 1\% of lncRNAs harbor ultraconserved elements, and 7\% of lncRNAs harbor diseaseassociated single-nucleotide polymorphisms. ${ }^{6}$

An increasing number of lncRNAs have been identified as key regulators of a wide range of cellular processes, including dosage compensation, imprinting, transcription, mRNA splicing, translation, nuclear and cytoplasmic trafficking, and cellular localization. Notably, ectopic expression of lncRNAs is associated with a great variety of diseases.

However, compared with mRNAs, lncRNAs have their own peculiar characteristics. First, the mean length of lncRNAs is shorter than that of mRNAs, with an average of $592 \mathrm{nt}$ compared to $2,453 \mathrm{nt}$ for mRNAs. Second, lncRNAs have fewer exons, although they harbor standard canonical splice sites. ${ }^{7}$ Third, the methylation level of the transcription start site of IncRNAs is higher than that of mRNAs; therefore, the expression level of lncRNAs is significantly lower. In addition, IncRNAs show strict tissue specificity. ${ }^{8}$ Furthermore, lncRNAs tend to correlate with transposable elements, especially with endogenous retroviruses, compared with protein-coding genes. ${ }^{9}$ Moreover, lncRNA conservation includes more than introns or random intergenic regions, but they are less conserved than mRNAs. ${ }^{10}$ Despite the fact that the conservation of some lncRNAs at the sequence level is not high, they may have the same functions. ${ }^{11,12}$ Diederichs ${ }^{11}$ indicated that the conservation of lncRNAs should include four dimensions: sequence, structure, function, and expression from synthetic loci. Despite the differences between IncRNAs and mRNAs, they share certain common characteristics. Large-scale studies revealed that many identified lncRNAs are transcribed by RNA polymerase II, which is the same as that for mRNA. They also share the same posttranscriptional mRNA processing, including 5'-capping, splicing, and poly-adenylation at the $3^{\prime}$ end. Certain transcription factors can bind to the promoter region of lncRNAs, such as c-myc, p53, and Sox2.

\section{Classification and functions of IncRNAs}

The most recent classification of lncRNAs is based on their location relative to that of target protein-coding genes. According to these criteria, lncRNAs can be classified as exonic, intronic, overlapping, or intergenic. Moreover, based on the transcriptional direction with respect to protein-coding genes, lncRNAs are divided into two groups, namely sense and antisense. ${ }^{7}$

According to transcriptional modes, lncRNAs can be categorized as cis-acting and trans-acting lncRNAs. Cisacting lncRNAs mediate gene expression based on their position in the vicinity of the target gene transcriptional site. However, trans-acting lncRNAs can control the expression of genes at any loci based on the recruitment of proteins to the target sites to participate in transcriptional regulation. lncRNAs hybridize with DNA or RNA molecules to form triple-stranded RNA-DNA structures that play essential roles in transcription. ${ }^{12,13}$

lncRNAs can be classified into various discrete subclasses on the basis of their function as follows (Figure 1). ${ }^{14}$

\section{Decoys}

lncRNA decoys exert biological functions by binding to proteins indirectly and playing a role in multiple processes of life.

\section{Scaffolds}

The second set of lncRNAs function as scaffolds, as lncRNAs act as platforms to bind relevant molecular complexes. Typically, HOTAIR acts as a bridging scaffold for the PRC2 and LSD1/CoREST/REST complex to suppress gene expression. PRC2 binds to an $89 \mathrm{bp}$ fragment in the $5^{\prime}$ end of HOTAIR, and the LSD1/CoREST/REST complex binds to a $646 \mathrm{bp}$ fragment in its $3^{\prime}$ end. ${ }^{15,16}$ Genome-wide RNA immunoprecipitation analysis has shown that $\sim 20 \%$ of the various types of lncRNAs are bound to PRC2. ${ }^{17}$ Another example of a molecular scaffold is Kcnq1ot1, which combines PRC2 and G9a to generate $\mathrm{H} 3 \mathrm{~K} 27 \mathrm{me} 3$ and $\mathrm{H} 3 \mathrm{~K} 9 \mathrm{me} 3$, leading to epigenetic silencing of genes. ${ }^{18}$ Indeed, several studies show that not only proteins but also lncRNAs play critical roles in bridging molecular components.

\section{Signal}

lncRNAs play critical roles in signal regulation and in the responses to various stimuli. IncRNAs are often expressed in a spatial- and temporal-specific pattern. Upon specific expression, they can modulate translation and integrate developmental cues. ${ }^{19}$ For instance, lincRNA-p21, which binds to hnRNP-K, promotes the proper localization of hnRNP-K and results in the silencing of p53-regulated genes. ${ }^{20}$ Certain lncRNAs are emerging as signals of functionally significant biological events because of their roles in regulating transcriptional activity or pathways.

\section{Sponges}

PTEN1 (pseudogene of PTEN) upregulates the tumor suppressor PTEN by attracting miRNAs to its $3^{\prime}$-untranslated region. ${ }^{21}$ The lncRNA GAPLINC acts as a "sponge" and modulates CD44 expression by attracting miR211-3p. ${ }^{22}$ The lncRNA antisense ncRNA in the INK4 locus (ANRIL) can 
A Decoys
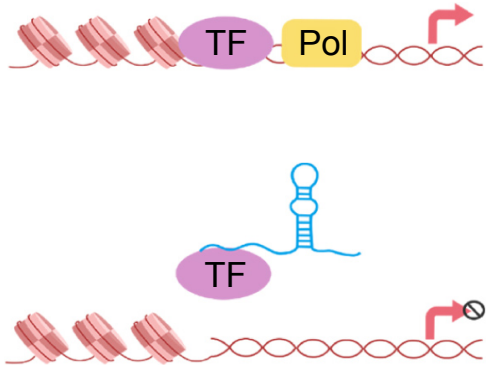

C Signal

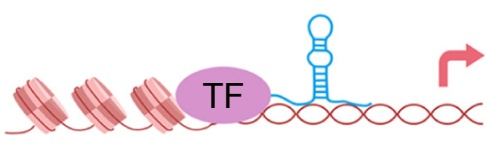

E Guide

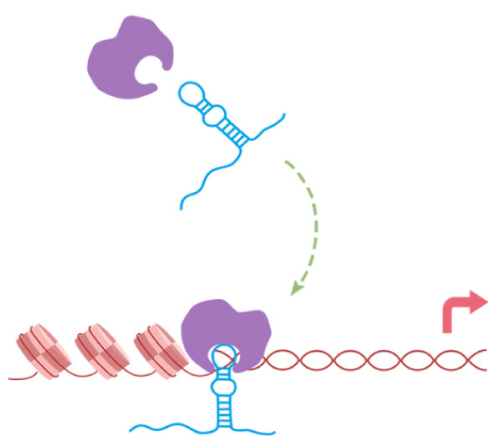

B Scaffolds

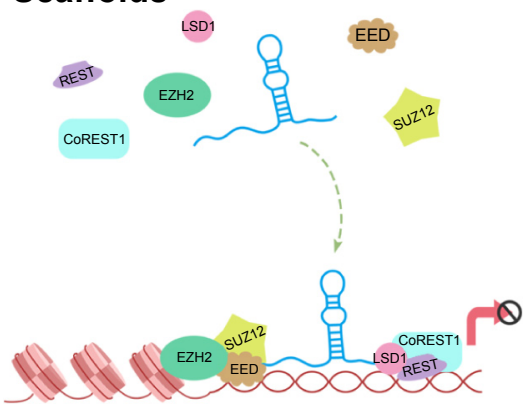

D Sponges
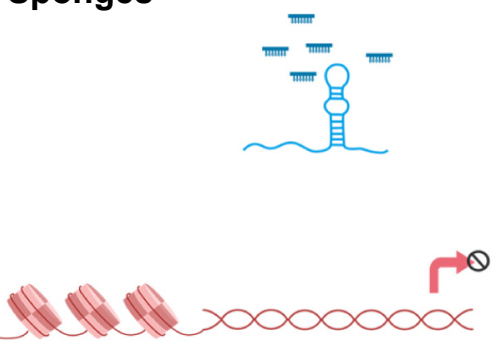

Figure I Overview of the five molecular functions of IncRNAs.

Notes: (A) IncRNAs act as decoys to attract transcription factors and influence protein activity. (B) In addition, the ability to aggregate different proteins has highlighted their usefulness as scaffolds. (C) IncRNAs also have a critical role in signal regulation. (D) IncRNAs can interact with miRNAs, acting as "sponges". (E) IncRNAs play essential roles in guiding chromatin-remodeling enzymes to target sites.

Abbreviations: IncRNAs, long noncoding RNAs; TF, transcription factor; Pol, polymerase.

function as a "sponge" to titrate $m i R-99 a / m i R-449 a$, thus activating $C D K 6$ and inactivating $\mathrm{p} 15^{\mathrm{INK} 4 \mathrm{~B}} / \mathrm{p} 16^{\mathrm{INK} 4 \mathrm{~A}}$. Consequently, E2F1 is released inappropriately and contributes to gastric cancer cell proliferation. ${ }^{23}$ lncRNAs therefore function as sponges by interacting with miRNAs and suppressing their effects on target sites. Recent evidence highlights a classification of circRNAs as miRNA sponges that contribute to the downregulation of target genes. Compared to linear RNAs, the half-life of circRNAs is longer. ${ }^{24}$ It is plausible that the duration and the effect of circRNAs have more advantages.

\section{Guide}

Multiple studies indicate that nuclear-retained lncRNAs function in guiding chromatin modifiers to specific genomic loci.
Typical is PRC2, which contains a histone methyltransferase (enhancer of zeste 2, EZH2) that inhibits gene expression via trimethylation of histone H3Lys27 (H3K27me3). ${ }^{25}$ In addition, chromatin conformation changes induced by nuclear-enriched lncRNAs can promote gene expression. ${ }^{26}$

\section{Regulation modes of IncRNAs IncRNAs involved in epigenetic regulation}

An example of the chromatin-modifying capabilities of lncRNAs is dosage compensation in mammals, which requires the preferential silencing of one parental allele. Xist gives rise to stable epigenetic silencing of large-scale genes in the X-chromosome by tethering PRC2 to the transcriptional site, inducing the formation of $\mathrm{H} 3 \mathrm{~K} 27 \mathrm{me} 3$ to inactivate 
heterochromatin. ${ }^{27}$ Another example is $\ln R N A$ p 21, which can change DNA methylation levels by promoting histone methyltransferase and DNA methyltransferase binding to target sites, thus affecting the expression of reprogramming genes. ${ }^{28}$

\section{IncRNAs participate in transcriptional regulation}

Evidence to date indicates that IncRNAs, which are transcribed from enhancers or promoters, can act in cis pattern to control transcriptional efficiency. lncRNAs transcribed from enhancers can affect their activity or help recruit protein factors. Among lncRNAs in prostate cancer, two overexpressed lncRNAs bind to the androgen receptor, promoting androgen receptor binding to an enhancer. ${ }^{29}$

\section{IncRNAs affect posttranscriptional processing}

Most genes are transcribed via tissue-specific and cell-specific alternative-splicing patterns in humans. ${ }^{30}$ Noteworthy is that the majority of lncRNAs are often similarly expressed in a spatial- and temporal-specific manner. Accumulating evidence indicates that $\operatorname{lncRNAs}$ may regulate alternative splicing by cis-acting mechanisms or by recruiting regulatory splicing factors. ${ }^{31,32}$ Recently, Gonzalez et al showed that a conserved antisense lncRNA transcribed from the FGFR2 locus in humans regulates alternative splicing by recruiting the histone demethylase KDM2a and polycomb group proteins. These findings suggested that lncRNAs can regulate alternative splicing through the establishment of a splicing-specific chromatin signature. ${ }^{33}$

\section{Dysregulation and functional roles of IncRNAs in lung cancer}

Lung cancer is often associated with aberrant lncRNA transcriptomes, including onco-lncRNAs and tumor suppressor lncRNAs. Here, we discuss recent discoveries that implicate aberrant lncRNAs in lung cancer (Table 1). In addition, we provide a framework of systematically functionalized lncRNAs and integrate them with the protein-coding RNA dimension in complex networks (Figure 2).

\section{Onco-IncRNAs MALATI}

\section{Characteristics of MALAT I}

$M A L A T 1$, also known as NEAT2, is located on chromosome $6 \mathrm{p} 24.3$ in humans with a length of $8.7 \mathrm{~kb} .^{11,12}$ MALAT1 is a well-characterized lncRNA with markedly high expression in most NSCLC types. MALAT1 generates a primary noncoding transcript that is enriched in the nucleus. ${ }^{34}$ Furthermore, the MALAT1 gene shows strong sequence conservation from humans to zebra fish. ${ }^{35}$ MALAT1 transcription is initiated from multiple promoters and produces different MALAT1 transcript variants. However, most MALAT1 transcripts, which harbor two distinct nuclear speckle localizational elements, are enriched in nuclear speckles, indicating essential role of MALAT1 in RNA metabolism. MALAT1 is modified at the $3^{\prime}$ end and forms a triple-helical structure, which may be the reason why MALAT1 appears as a very stable lncRNA. ${ }^{36,37}$ The half-life of $M A L A T 1$ ranges from 9 to 16.5 hours. ${ }^{38}$ After modification, $M A L A T 1$ generates a second small mascRNA that is localized to the cytoplasm. ${ }^{39}$ MALAT1 binds to the unmethylated $\mathrm{PRC} 2$ protein, therefore contributing to PRC2 preferential binding to $\mathrm{H} 2 \mathrm{AK} 5 \mathrm{ac}$ and $\mathrm{H} 2 \mathrm{AK} 13 \mathrm{ac}$, marking transcriptional activation. ${ }^{40}$ At the transcriptional level, several studies have shown that MALAT1 regulates gene expression, such as that of growth control genes. MALAT1 affects the phosphorylation levels of serine/arginine (SR) splicing factors, such as B-MYB, leading to changes in gene expression. ${ }^{12}$ MALAT1 also regulates gene expression at the posttranscriptional level. ${ }^{41}$ For instance, MALAT1 affects a minor subset of transcripts in the process of alternative splicing, such as RNPS1, PRP6, and SON. ${ }^{42}$ In summary, MALAT1 can modulate gene expression both at the transcriptional and posttranscriptional level.

\section{MALATI in lung cancer}

MALAT1, which is found in abundance in various tissues and cell lines, is successfully knocked out by the zinc finger nuclease technique in A549 cells. MALAT1 has been shown to be a critical regulator of the metastasis phenotype in lung cancer cells. ${ }^{43}$ In A549 cells, inhibition of MALAT1 downregulates the expression of motility-associated genes, including HMMR, AIM1, SLC26A2, LAYN, CCT4, ROD1, CTHRC, and FHL1.44,45 Xenograft models have confirmed this effect. The prevailing view is that MALAT1 participates in the regulation of motility-related genes to enhance the motility of lung ADC cells. ${ }^{45}$ Recently, Shen et al ${ }^{46}$ demonstrated that MALAT1 overexpression promotes lung cancer brain metastasis by inducing epithelial-to-mesenchymal transition (EMT). Another study suggested that MALAT1 is involved in cell cycle regulation at the level of G2/M phase progression. MALAT1 interacts with nuclear hnRNP C and promotes hnRNP $\mathrm{C}$ translocation to the cytoplasm in the $\mathrm{G} 2 / \mathrm{M}$ phase. ${ }^{47}$ In addition to its effect on cell cycle progression, MALAT1 affects the expression of the proapoptotic factor Bcl-2, which is specifically associated with prognosis in NSCLC. ${ }^{48}$ Moreover, a meta-analysis and various studies 
Table I Summary of IncRNAs in lung cancer

\begin{tabular}{|c|c|c|c|c|c|c|c|c|}
\hline $\begin{array}{l}\text { Type of } \\
\text { IncRNA }\end{array}$ & Name & Location & $\begin{array}{l}\text { Length } \\
\text { (kb) }\end{array}$ & $\begin{array}{l}\text { Expression } \\
\text { level }\end{array}$ & Property & $\begin{array}{l}\text { Intersection molecules } \\
\text { and pathway }\end{array}$ & $\begin{array}{l}\text { Cell processes and clinical } \\
\text { features }\end{array}$ & References \\
\hline \multirow[t]{3}{*}{ Intergenic } & MALATI & 6p24.3 & 8.7 & Up & Oncogenic & $\begin{array}{l}\text { Affects expression of } \mathrm{Bcl}-2 \\
\text { and metastasis-related } \\
\text { genes }\end{array}$ & $\begin{array}{l}\text { Promotes cell growth, } \\
\text { metastasis, and EMT; inhibits } \\
\text { apoptosis; poor survival }\end{array}$ & $\begin{array}{l}11,12 \\
34-49\end{array}$ \\
\hline & HOTAIR & $12 q 13.13$ & 2.15 & Up & Oncogenic & $\begin{array}{l}\text { Induced by Col-I, HIF-I } \alpha \text {. } \\
\text { Promotes expression of } \\
\text { gelatinases. Represses cell- } \\
\text { adhesion related genes, } \\
\text { p2I, and HOXA5 }\end{array}$ & $\begin{array}{l}\text { Promotes cell growth, invasion, } \\
\text { metastasis, EMT and relapse }\end{array}$ & $25,50-64$ \\
\hline & MEG3 & $14 q 32.3$ & 1.6 & Down & $\begin{array}{l}\text { Tumor } \\
\text { suppressive }\end{array}$ & Affects expression of p53 & $\begin{array}{l}\text { Inhibits proliferation. Induces } \\
\text { apoptosis }\end{array}$ & $88-91$ \\
\hline \multirow[t]{3}{*}{ Intronic } & SOX2-OT & $3 p 26.33$ & 4.2 & Up in SCC & Oncogenic & $\begin{array}{l}\text { Inhibits the expression of } \\
\text { EZHP }\end{array}$ & $\begin{array}{l}\text { Promotes cell growth. Poor } \\
\text { survival }\end{array}$ & $65-68$ \\
\hline & SPRY4-IT & $15 q 3 \mid$ & 0.69 & Down & $\begin{array}{l}\text { Tumor } \\
\text { suppressive }\end{array}$ & $\begin{array}{l}\text { Silenced by EZHP. Inhibits } \\
\text { the expression of EMT } \\
\text { markers }\end{array}$ & $\begin{array}{l}\text { Inhibits growth, invasion, and } \\
\text { metastasis. Induces apoptosis }\end{array}$ & $92-96$ \\
\hline & HNFIA-AS & $12 q 24$ & 2.46 & Up in ADC & Oncogenic & $\begin{array}{l}\text { Affects EMT-related genes } \\
\text { via DNMTI }\end{array}$ & $\begin{array}{l}\text { Promotes cell growth and } \\
\text { metastasis }\end{array}$ & 1 \\
\hline \multirow[t]{3}{*}{ Overlapping } & ANRIL & $9 p 21.3$ & 126 & Up & Oncogenic & $\begin{array}{l}\text { Represses KLF2 and p2I } \\
\text { via PRC2 }\end{array}$ & $\begin{array}{l}\text { Promotes cell growth and } \\
\text { metastasis. Inhibits apoptosis } \\
\text { Poor survival }\end{array}$ & $69-73$ \\
\hline & $\mathrm{HI9}$ & IIqI5.5 & 2.3 & Up & Oncogenic & $\begin{array}{l}\text { Affects expression of } \\
\text { miR } 675 \text { and HGF/SF } \\
\text { Induced by cigarette smoke }\end{array}$ & Unknown & $74-81$ \\
\hline & PANDAR & $6 \mathrm{p} 21.2$ & 1.5 & Down & $\begin{array}{l}\text { Tumor } \\
\text { suppressive }\end{array}$ & $\begin{array}{l}\text { Affects expression of Bcl-2 } \\
\text { via NF-YA }\end{array}$ & $\begin{array}{l}\text { Inhibits proliferation. Induces } \\
\text { apoptosis }\end{array}$ & 97,98 \\
\hline \multirow[t]{3}{*}{ Exonic } & CARLO-5 & $8 q 24.21$ & 1.6 & Up & Oncogenic & $\begin{array}{l}\text { Suppresses } \mathrm{p} 16, \mathrm{p} 2 \mathrm{I} \text { and } \\
\mathrm{p} 27 \text { and EMT markers }\end{array}$ & $\begin{array}{l}\text { Affects cell cycle, proliferation, } \\
\text { and invasion, EMT. Poor survival }\end{array}$ & 82,83 \\
\hline & GAS5 & Iq25 & 0.65 & Down & $\begin{array}{l}\text { Tumor } \\
\text { suppressive }\end{array}$ & $\begin{array}{l}\text { Affects expression of E2FI, } \\
\text { P2I, and p } 53 \text {. Suppresses } \\
\text { miR-2I expression }\end{array}$ & $\begin{array}{l}\text { Inhibits proliferation. Induces } \\
\text { apoptosis }\end{array}$ & $99-108$ \\
\hline & MVIH & $10 q 22$ & & Up & Oncogenic & $\begin{array}{l}\text { Affects expression of } \\
\text { MMP2/MMP9 }\end{array}$ & $\begin{array}{l}\text { Promotes proliferation and } \\
\text { invasion. Poor survival }\end{array}$ & 84 \\
\hline \multirow[t]{4}{*}{ Unknown } & TUG I & $22 q 12.2$ & 7.1 & Down & $\begin{array}{l}\text { Tumor } \\
\text { suppressive }\end{array}$ & $\begin{array}{l}\text { Induced by } \mathrm{P} 53 \text {, represses } \\
\mathrm{HOXB7} \text { via } \mathrm{PRC2}\end{array}$ & $\begin{array}{l}\text { Inhibits proliferation. Induces } \\
\text { apoptosis }\end{array}$ & $109-112$ \\
\hline & BANCR & $9 q 21.11$ & 0.69 & Down & $\begin{array}{l}\text { Tumor } \\
\text { suppressive }\end{array}$ & $\begin{array}{l}\text { Inhibits the expression of } \\
\text { EMT markers }\end{array}$ & $\begin{array}{l}\text { Inhibits migration, invasion, } \\
\text { metastasis, EMT. Induces } \\
\text { apoptosis }\end{array}$ & $113-117$ \\
\hline & EVADR & $6 q 13$ & 0.39 & Up in ADC & Oncogenic & $\begin{array}{l}\text { Induced by MER48 ERV } \\
\text { element }\end{array}$ & Unknown & 87 \\
\hline & PVTI & $8 q 24.21$ & 210 & Up & Oncogenic & Induced by $\mathrm{p} 53$ & $\begin{array}{l}\text { Induces proliferation, invasion, } \\
\text { and metastasis. Poor survival }\end{array}$ & $85-86$ \\
\hline
\end{tabular}

Notes: Up, upregulated; down, downregulated.

Abbreviations: IncRNAs, long noncoding RNAs; EMT, epithelial-to-mesenchymal transition; SCC, squamous cell carcinoma; ADC, adenocarcinoma; MMP, matrix metalloproteinase.

have shown that high $M A L A T 1$ expression is related to poor overall survival in NSCLC. ${ }^{49}$

\section{HOTAIR}

\section{Characteristics of HOTAIR}

HOTAIR is located on chromosome 12q13.13 in humans, and has a length of $2.1 \mathrm{~kb}$. There are four gene clusters (HOXA, HOXB, HOXC, and HOXD) and 39 HOX genes in the genome..$^{25}$ These clusters generate numerous lncRNAs that are often expressed in a spatial- and temporal-specific pattern. ${ }^{50}$ Although HOTAIR is located in the HOXC locus, it has been shown to repress gene expression in the HOXD locus. In addition, the secondary structure of HOTAIR contains four independently folding modules, two of which are evolutionarily conserved protein-binding domains. ${ }^{51}$ HOTAIR is enriched in the nucleus but is also expressed in the cytoplasm..$^{52}$ HOTAIR has little sequence conservation in humans and mice, but the molecular mechanism is similar 


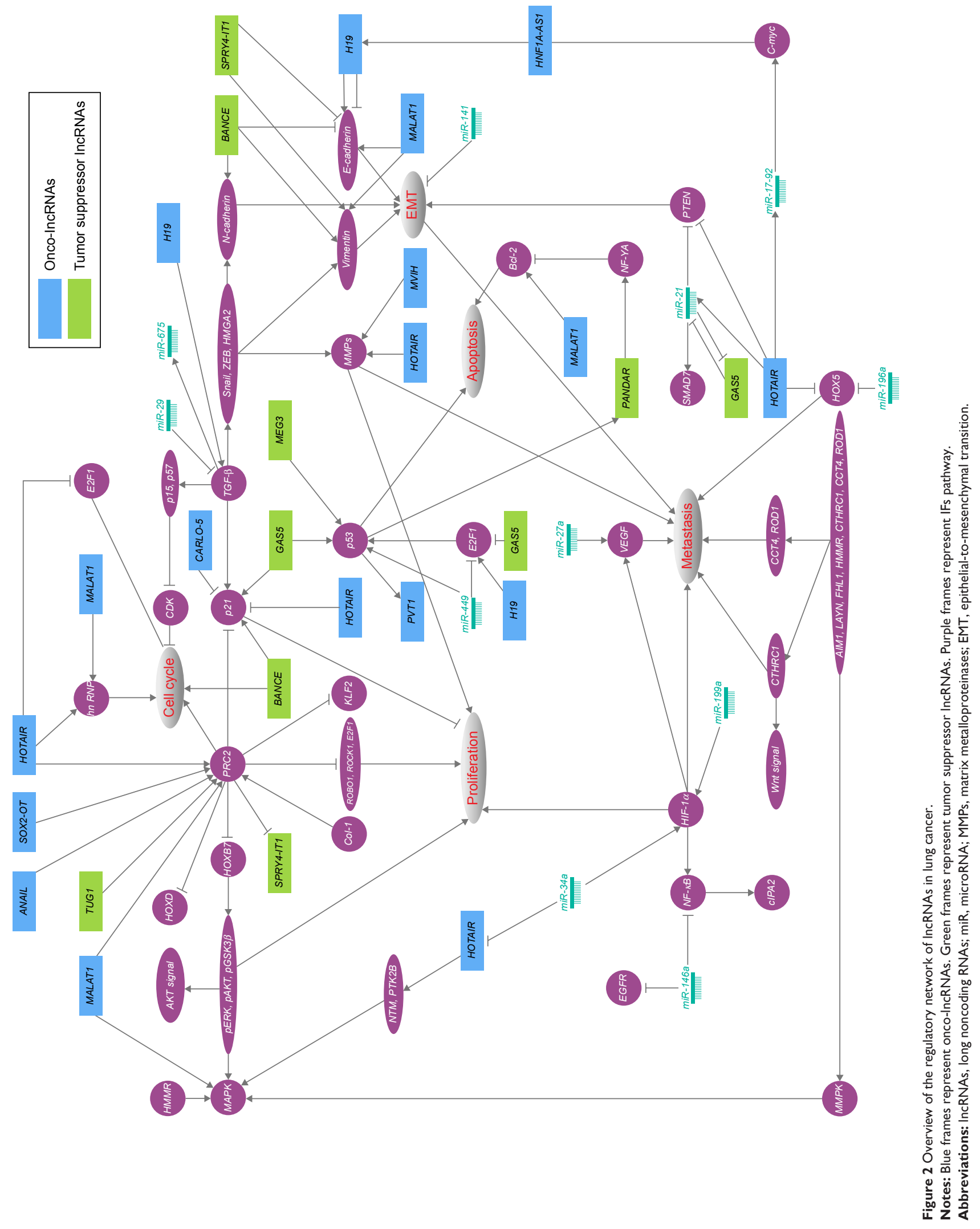


in the two species. Reciprocally, the conserved lncRNA sequence does not always possess the same function in other species as expected.

HOTAIR-mediated epigenetic gene silencing is dependent on its function as a bridge scaffold for PRC2 and LSD1/ CoREST/REST. PRC 2 binds to the $5^{\prime}$ end of HOTAIR and regulates chromosome occupancy by EZH2 (a subunit of PRC2), which leads to histone H3 lysine 27 trimethylation of the HOXD locus. Meanwhile, the LSD1/CoREST/REST complex binds to the $3^{\prime}$ end of HOTAIR ${ }^{53}$ HOTAIR represses gene expression by increasing the occupation of $\mathrm{H} 3 \mathrm{~K} 27 \mathrm{me} 3$ and decreasing the occupation of $\mathrm{H} 3 \mathrm{~K} 4 \mathrm{me} 3$ on the promoter in a trans-acting manner. ${ }^{54}$ In addition to its role in the PRC2 and LSD1/CoREST/REST complexes, HOTAIR acts as a scaffold for E3 ubiquitin ligases and their corresponding substrates, namely E3 ubiquitin ligase Dzip3 and its substrate Ataxin-1, resulting in proteolysis. ${ }^{55}$ Furthermore, HOTAIR harbors a target site for $m i R-34 a^{56}$ and $m i R-141$ in its exon 6 , both of which can attenuate the expression of HOTAIR. Exon 6 of HOTAIR contains a target site for let-7i that mediates the formation of a hetero-tetramer containing let-7i, Ago2, HOTAIR, and HuR. ${ }^{57}$

\section{HOTAIR in lung cancer}

Ectopic expression of HOTAIR has been reported in a plethora of cancerous tissues. High HOTAIR levels are associated with invasion and metastases and linked to an advanced stage of disease and poor survival in patients with lung cancer. ${ }^{58-60}$ EMT mediates the invasive phenotype of lung cancer cells. HOTAIR may promote the EMT process of lung epithelial cells by distinct mechanisms. One of these mechanisms is transcriptional repression of HOXA5 gene. $H O X A 5$ is related to postnatal lung development. It is likely that HOTAIR and miR-196a act in common to repress the expression of $H O X A 5$, therefore contributing to dedifferentiation during lung tumorigenesis. ${ }^{61}$ Moreover, HOTAIR facilitates the process of EMT by inhibiting the expression of cell adhesion-related genes in small-cell lung cancer epithelial cells. ${ }^{59}$ Meanwhile, tumor-promoting type 1 collagen, which is a potent inducer of EMT, can modulate the translational control of HOTAIR in NSCLC cells. ${ }^{62}$ In addition to the repression of EMT inhibitors and the promotion of EMT, HOTAIR also affects the expression of gelatinase, a matrix metalloproteinase (MMP) that plays a role in triggering invasion in lung cancer cells. ${ }^{58}$ HOTAIR can promote resistance to cisplatin via downregulation of $\mathrm{p} 21$ (WAF1/CIP1) protein levels in lung ADC cells. ${ }^{63}$ Furthermore, HOTAIR as a direct target of HIF-1 $\alpha$, promotes cell proliferation, migration, and invasion in hypoxic NSCLC. Evidence indicates that HIF- $1 \alpha$ binds to HOTAIR via interaction with the upstream region of HOTAIR in NSCLC cells. ${ }^{64}$ The upregulation of HOTAIR has been shown to have a negative impact on lung cancer by regulating genes involved in invasion, metastasis, and poor survival. ${ }^{59}$

\section{SOX2-OT}

SOX2-OT is located on chromosome 3p26.33 in humans and has a length of $4.2 \mathrm{~kb}$. SOX2-OT is an intronic lncRNA that overlaps with the $S O X 2$ gene, which is a major regulator of pluripotency. ${ }^{65}$ Recent studies have shown that $S O X 2$ and SOX2-OT have similar expression patterns in lung SCC and ADC tissues. ${ }^{66}$ There are multiple transcription initiation sites in the human and mouse SOX2-OT locus, leading to many spliced variants. ${ }^{67}$ In addition, the human genomic region of SOX2-OT is characterized by multiple conserved transcription factor-binding sites. These sites have essential roles in the tumorigenesis process. ${ }^{65}$ SOX2-OT is expressed at higher levels in human primary lung cancer tissues than in adjacent non-tumor tissues. Typically, SOX2-OT exhibits significantly higher expression in SCC of the lung than in ADC. ${ }^{68}$ With respect to the mechanism of SOX2-OT, Hou et al showed that knockdown of SOX2-OT expression leads to cell cycle arrest at $\mathrm{G} 2 / \mathrm{M}$ phase through the modulation of the expression of EZH2. Meanwhile, its expression level is significantly correlated with cell proliferation and colony formation ability in lung cancer cell lines. ${ }^{66}$ This study further indicates that high SOX2-OT expression predicts poor survival in lung cancer patients.

\section{HNFIA-ASI}

HNF1A-AS1 is located on chromosome 12q24 and has a length of $2.46 \mathrm{~kb}$. Overexpression of $H N F 1 A-A S 1$ has been reported in lung ADC tissues compared with the corresponding non-tumor tissues. In addition, elevated expression of HNF1A-AS1 is linked to tumor-node-metastasis (TNM) stage, tumor size, and lymph node metastasis. HNF1A-AS1 can regulate EMT-related protein expression via binding to DNMT1, therefore regulating cell growth and metastasis both in vitro and in vivo. ${ }^{1}$

\section{ANRIL}

ANRIL is derived from the p15/CDKN2B-p16/CDKN2Ap14/ARF gene cluster, which maps to human chromosome $9 \mathrm{p} 21.3$ with a length of $126 \mathrm{~kb}$. This gene family is associated with cutaneous malignant melanoma and neural system tumors. ANRIL includes several isoforms with 
tissue-specific expression because it consists of 19 exons. ${ }^{69}$ Recently, elevated levels of ANRIL have been reported in NSCLC tissues, and its expression level is significantly correlated with poor prognosis. siRNA-mediated knockdown of $A N R I L$ results in the inhibition of cell proliferation and the promotion of apoptosis both in vitro and in vivo. ${ }^{70}$ An ongoing study indicates that the subcellular localization of ANRIL is mostly in the cell nucleus. ANRIL is indicated as a "decoy", and it represses KLF2 and p21 transcription by binding to PRC2 in NSCLC PC9 cells, which sheds light on the effect of ANRIL on NSCLC cell proliferation and apoptosis partly in trans. ${ }^{70}$ Generally, KLF2 as a tumor suppressor is significantly downregulated in various cancers, leading to inhibition of cell proliferation via $\mathrm{KRAS}^{71}$ ANRIL can regulate the transcription of $m i R-99 a$ and $m i R-449 a$ by recruiting the PRC2 complex in gastric cancer. ${ }^{72}$ Recently, Ren et $\mathrm{al}^{73}$ demonstrated that high expression of $m i R-449 a$ attenuates lung cancer cell proliferation, and the downregulation of $m i R-449 a$ is correlated with a shorter disease-free survival of patients. It is plausible that $A N R I L$ modulates the expression of $m i R-449 a$, thereby inhibiting the proliferation of lung cancer cells during lung tumorigenesis.

\section{HI9}

\section{Characteristics of $\mathrm{H} / 9$}

H19 is located on chromosome 11q15.5 in humans and has a length of $2.3 \mathrm{~kb}$. H19 is a paternally imprinted gene that is spliced into five exons. The $H 19$ gene locus is complex, harboring conserved $m i R-675$ and antisense protein-encoding transcript (HOTS), which is a tumor suppressor. ${ }^{74}$ Another pro-tumorigenic antisense transcript, $91 \mathrm{H}$, overlaps with the $H 19$ gene locus. ${ }^{75} \mathrm{H} 19$ and its nearby gene IGF2 show uniparental mono-allelic expression. There is an imprinting control region (ICR) between them. The ICR is unmethylated on maternal chromosomes, where it binds to the transcription factor CTCF and inhibits the enhancer from binding to the ICR. As a result, the enhancer binds to H19 and induces its expression. Conversely, on paternal chromosomes, the ICR is methylated and binds to the enhancer, resulting in $H 19$ downregulation. ${ }^{76} \mathrm{H} 19$ can act in both $\mathrm{cis}$ and trans patterns: for instance, $H 19$ regulates the imprinting of IGF2 by silencing the expression of neighboring genes. An example of $H 19$ acting in trans pattern is its role as a molecular sponge for miRNA let-7, which is involved in inducing EMT. ${ }^{77}$

\section{HI 9 in lung cancer}

Evidence to date indicates that $H 19$ is associated with various tumorigenesis signaling pathways, including the p53 and HIF-1 $\alpha$, TGF- $\beta$, Bcr-Abl, Wnt/ $\beta$-catenin, and
HGF pathways. ${ }^{78}$ In lung cancer cells, H19 is induced by hypoxic stress via a p53-dependent manner. Knockdown of H19 expression in hypoxia has a suppressing effect on cancer cell proliferation, anchorage-independent growth, and colony formation. ${ }^{79,80}$ Furthermore, knockdown of H19 can reverse the tumorigenic and scattering effect of $\mathrm{HGF} / \mathrm{SF}$ on A549 cells. ${ }^{79}$ The overexpression of $H 19$ has a negative impact on lung cancer. Notably, the upregulated H19 is loss of imprinting independent in the airway epithelia of smokers in comparison with nonsmokers. ${ }^{81}$

\section{CARLO-5}

CARLO-5 is located on chromosome 8q24.21 in humans and has a length of $1.6 \mathrm{~kb}$. CARLO-5 is significantly upregulated in NSCLC tissues. Overexpression of CARLO-5 in NSCLC tissues is significantly correlated with advanced TNM stage. The expression of $\mathrm{p} 16, \mathrm{p} 21$, and p27, which are G0/G1 arrest markers, decreases with the downregulation of CARLO-5. ${ }^{82}$ High level of CARLO-5 expression is a prognostic indicator of poor patient survival. Moreover, elevated expression of CARLO-5 is associated with increased proliferation and invasion ability, partially through the modulation of EMT. ${ }^{83}$

\section{$\mathrm{MVIH}$}

MVIH is located on chromosome 10q22 in humans. Overexpression of $M V I H$ has been reported in NSCLC tissues, and its expression level is significantly correlated with TNM stage and tumor size. High levels of $M V I H$ expression are prognostic indicators of poor survival. ${ }^{84}$ siRNA-mediated knockdown of $M V I H$ inhibits cell proliferation and invasion, partly via modulating the expression of $M M P 2$ and $M M P 9$. $M M P s$ are involved in multiple biological processes, including remodeling of extracellular matrix, cell proliferation, differentiation, and metastasis.

\section{PVTI}

PVT1 is located on chromosome $8 \mathrm{q} 24.21$ in humans and has a length of $210 \mathrm{~kb}$. The similar expression patterns of $P V T 1$ and MYC gene might be explained by the shared genomic locus between them. A study identified a p53 transcription factorbinding site in the $P V T 1$ promote region. ${ }^{85}$ Overexpression of $P V T 1$ in NSCLC tissues is significantly correlated with TNM stage. In addition, patients with high levels of $P V T 1$ expression show poor survival. ${ }^{86}$ Knockdown of $P V T 1$ expression inhibits lung cancer cell proliferation, migration, and invasion.

\section{EVADR}

EVADR is located on chromosome $6 \mathrm{q} 13$ in humans and has a length of $0.39 \mathrm{~kb}$. Recent evidence shows that EVADR is 
overexpressed in ADC tissues, including lung ADC, and is correlated with decreased patient survival. Among nine MER48-associated lncRNAs, EVADR is the only one that is consistently expressed in ADC tissues. EVADR expression is regulated via an active promoter provided by the MER48 endogenous retrovirus element. ${ }^{87}$

\section{Tumor suppressor IncRNAs MEG3}

MEG3 is located on chromosome 14q32.3 in humans and has a length of $1.6 \mathrm{~kb}$. Previous evidence indicates that $M E G 3$ is a tumor suppressor because of its role in modulating angiogenesis. ${ }^{88}$ MEG3 can act in both p53-dependent and p53independent manner during different processes. However, overexpression of $M E G 3$ decreases NSCLC cell proliferation and induces apoptosis via the activation of $\mathrm{p} 53 .{ }^{89}$ In addition, $M E G 3$ expression is deregulated in NSCLC tissues, and a low expression level is significantly related with higher TNM stage, increased tumor size, and poor patient survival..$^{90,91}$

\section{SPRY4-IT I}

SPRY4-IT1 is located on chromosome 5q31 in humans and has a length of $0.69 \mathrm{~kb}$. SPRY4-IT1 is upregulated in melanoma, esophageal SCC, and clear cell renal cell carcinoma, suggesting a common oncogenic role. ${ }^{92-94}$ Sun et $\mathrm{al}^{95}$ showed that SPRY4-IT1 is significantly downregulated in $94.2 \%$ of NSCLC cancerous tissues compared with normal tissues, which suggests an anti-oncogenic role. Ectopic expression of SPRY4-IT1 is associated with tumor size, advanced pathological stage, lymph node metastasis, and overall survival time in NSCLC patients. Reduced SPRY4-IT1 expression is an independent prognostic marker for NSCLC. EZH2, a methyltransferase and a catalytic subunit of PRC2, is overexpressed in NSCLC, ${ }^{96}$ and its downregulation prevents it from binding to the SPRY4-IT1 promoter region. This decreases the H3K27me3 modification, resulting in the inhibition of SPRY4-IT1 expression. SPRY4-IT1 has also been shown to promote NSCLC cell proliferation and metastasis by modulating the process of EMT. ${ }^{95}$

\section{PANDAR}

$P A N D A R$ is located on chromosome 6p21.2 in humans and has a length of $1.5 \mathrm{~kb} \cdot{ }^{97}$ Although $P A N D A R$ is transcribed in antisense to $C D K N 1 A$, it is not a linked transcript of CDKN1A. ${ }^{98}$ PANDAR is a direct transcriptional target of p53 in NSCLC cells, and can modulate Bcl-2 expression by binding to NF-YA, thus affecting NSCLC cell apoptosis. ${ }^{97}$ $P A N D A R$ interacts with NF-YA (NF-YA is related to tumorigenesis) to decrease proapoptotic gene expression in a p53-dependent manner in normal human fetal lung fibroblasts. In NSCLC tissues, PANDAR interacts with NF-YA and is deregulated. PANDAR downregulation is associated with increased tumor size and advanced TNM stage. $P A N$ $D A R$ expression is an independent prognostic predictor for NSCLC. Moreover, PANDAR, a transcriptional target of $\mathrm{p} 53$, affects NSCLC cell apoptosis partly by modulating Bcl-2 transcription through binding to NF-YA, thus affecting the proliferation of NSCLC cells in vitro and in vivo. ${ }^{97}$

\section{GAS5}

\section{Characteristics of GAS5}

GAS5, comprising 12 exons, is located on chromosome 1q25 in humans and has a length of $0.65 \mathrm{~kb}$. With respect to this locus, there are ten C/D box snoRNAs transcribed from its intronic regions. In addition, these snoRNAs have increasingly been linked to the functions of $G A S 5 .{ }^{99} G A S 5$ plays an essential role in cell apoptosis and growth. Evidence to date indicates that $G A S 5$ modulates the activity of glucocorticoidresponsive genes. In this process, GAS5 represents a clear example of a decoy lncRNA, which competitively binds to the glucocorticoid receptor and prevents it from binding to glucocorticoid response elements. ${ }^{100}$

\section{GAS5 in lung cancer}

Multiple studies have indicated that GAS5 acts as a tumor suppressor in various cancers, such as gastric cancer, ${ }^{101}$ hepatocellular cancer, ${ }^{102}$ and colorectal cancer, ${ }^{103}$ because of its role in the inhibition of proliferation and promotion of apoptosis. In NSCLC patient samples, decreased expression of GAS5 is linked to advanced TNM stage and increased tumor size. ${ }^{104}$ Increased expression of GAS5 deregulates E2F1 and drives the expression of p21 p53 in NSCLC cells, indicating that GAS5 has a regulatory effect on NSCLC cell proliferation. ${ }^{105}$ The activity of GAS5 can be regulated by miR-21, which has a putative binding site in GAS5. In turn, GAS5 suppresses miR-21 expression in a feedback loop between them. ${ }^{106}$ Dong et $\mathrm{al}^{107}$ showed that overexpression of GAS5 in the lung ADC A549 cell line reverts gefitinib resistance, suggesting its tumor-suppressive function. Moreover, overexpression of GAS5 reverses the resistance to EGFR-tyrosine kinase inhibitors in ADC in vitro and in vivo. Generally, increased EGFR is related to poor prognosis in NSCLC patients. ${ }^{108}$ This study further indicated that GAS5 has an anti-oncogenic role.

\section{TUG I}

TUG1 is located on chromosome $22 \mathrm{q} 12.2$ in humans and has a length of $7.1 \mathrm{~kb}$. The TUG1 gene displays a high level 
of conservation in the human, mouse, rat, dog, and cow genomes. ${ }^{109}$ TUG1 is involved in photoreceptor development and is deregulated in many kinds of human cancers. In NSCLC, TUG1 possesses tumor suppressor features such as inhibition of cell proliferation and promotion of apoptosis. $T U G 1$, which is induced by $\mathrm{p} 53$, is found binding to PRC2 and epigenetically regulates the expression of $H O X B 7 .{ }^{110}$ Thus, it is plausible that TUG1 modulates NSCLC cell growth via the AKT and MAPK signaling pathways because HOXB7 participates in these pathways. Moreover, patients with low level of TUG1 expression display a higher TNM stage, increased tumor size, and relatively poor overall survival. ${ }^{110}$ TUG1 has an oncogenic role in NSCLC, but it is a bona fide ncRNA in other cancer entities, including urothelial carcinoma of the bladder ${ }^{111}$ and osteosarcoma. ${ }^{12}$

\section{BANCR}

$B A N C R$ is located on chromosome $9 \mathrm{q} 21.11$ and has a length of $0.69 \mathrm{~kb} . B A N C R$ is upregulated in malignant melanoma, colorectal carcinoma, and papillary thyroid carcinoma tissues, suggesting a common oncogenic role. ${ }^{113-115}$ However, Sun et al showed that BANCR is significantly downregulated in NSCLC cancerous tissues compared with normal tissues. ${ }^{116}$ In addition, deregulated expression of BANCR is associated with increased tumor size, advanced pathological stage, lymph node metastasis, and poor survival in NSCLC patients. Reduced BANCR expression is an independent prognostic marker for NSCLC. Furthermore, knockdown of BANCR expression leads to the promotion of cell migration and invasion but inhibition of metastasis. It is plausible that downregulated $B A N C R$ promotes cell proliferation by downregulating p21 expression. ${ }^{117}$ Subsequent studies further indicate that $B A N C R$ has a critical role in EMT via modulation of E-cadherin, N-cadherin, and Vimentin expression. In sum, BANCR is proposed to modulate NSCLC cell-invasive and metastatic ability partially by modulating the EMT process. ${ }^{116}$

\section{Discussion}

Lung cancer is responsible for the largest number of cancerrelated deaths around the world. One of the main barriers to the success of lung cancer therapy is the lack of tumor biomarkers for early diagnosis. In the previous studies, evidences have mainly focused on elucidation of lncRNAs in cellular and mouse models. As shown in Table 1, the expression of MALAT1, HOTAIR, SOX2-OT, HNF1A-AS1, ANRIL, $M V I H$, and $P V T 1$ is associated positively with tumor size; reciprocally, the expression of MEG3, SPRY4-IT1, GAS5, and $T U G 1$ is negatively correlated. Besides, the expression of MALAT1, HOTAIR, HNF1A-AS1, ANRIL, and PVT1 is associated positively with lymph node metastases, whereas the expression of SPRY4-ITI and BANCR is negatively correlated. Indeed, to accurately and comprehensively understand the role of lncRNAs in human, large clinical cases of pathological characteristics as well as the prognosis are needed. The previous studies have indicated that overexpression of MALAT1, SOX2-OT, ANRIL, CARLO-5, MVIH, and PVT1 is a negative prognostic marker for patient survival. Indeed, the clinical integration of IncRNAs with respect to prognostic and predictive biomarker signatures will increase the therapeutic benefit. Here, we summarize the recent research and regulatory networks of lncRNAs (Figure 2) in lung cancer. Interestingly, the key role of $P R C 2$ in modulating proliferation and cell cycle of lung cancer cells has been emerging. PCR2 indirectly functions as a double-edged sword through ROB1, ROCK1, and E2F1. First, MALAT1, ANAIL, SOX2-OT, and HOTAIR promote proliferation and cell cycle by regulating $P R C 2$. TUG1 inhibits proliferation by regulating $P R C 2$. Meanwhile, $P R C 2$ is able to inhibit the expression of SPRY4-IT1. Several growth-related genes including $\mathrm{p} 21$ and $\mathrm{p} 53$ have been shown in the hinge of network. BANCE, $G A S 5$, and $M E G 3$ enhance activity of these tumor suppressor genes. CARLO-5 and HOTAIR have been proposed to highlight oncogenic feature by inhibiting the expression of $\mathrm{p} 21$ and p53. Generally, MMPs play a critical role in tumor cell growth and metastasis by altering the environments in which the cells grow. ${ }^{118}$ We have shown that HOTAIR and MVIH possibly regulate proliferation and metastatic ability of lung cancer cells. Noteworthy is that the altering expression of E-cadherin, Vimentin, and $N$-cadherin is a fundamental event in EMT. ${ }^{119}$ It is plausible that MALAT1, BANCE, SPRY4-IT1, and $\mathrm{H} 19$ act in concert with them to regulate the progress of EMT during lung tumorigenesis. Additionally, miRNAs as high-potential biomarkers have critical position in regulatory network of lung cancer; for example, miR-196a represses $H O X 5$ expression, thereby promoting metastasis. It is very likely that lncRNAs harbor miRNA seed regions and enrich target RNA-binding motifs. Thus, miRNAs are proposed to modulate lung tumorigenesis by lncRNAs.

Although an impressive number of studies in the last decade focused on the characteristics and functions of ncRNAs, research is still in its infancy and presents great challenges. First, as the sequence and structure of lncRNAs are only poorly conserved, the canonical knockdown and knockout methods may have no effect. In addition, ectopic expression of lncRNAs may not show obvious phenotypes 
as with protein-coding transcripts. Second, reference value is not always high between different researches, owing to different and multiple functions of lncRNAs in different tissues and cells. Therefore, elucidating the biological functions of lncRNAs is not easy. Third, the limited bioinformatical resources are another reason. Current lncRNA annotation is lacking compared with other RNA databases. Similarly, bioinformatic tools, such as lncRNA secondary structure prediction, remain to be developed. Unraveling the functions and regulatory mechanisms of lncRNAs in lung cancer might be a future breakthrough to improve our understanding of this network. The integration of miRNA and lncRNA signature profiling in lung cancer may be a useful tool for clinical applications.

\section{Conclusion}

lncRNAs are increasingly being recognized as critical molecules in various biological processes. In addition to the various types, there is a large number of lncRNAs, and they show numerous modes of interaction. Based on the location concerning the nearest protein-coding gene, lncRNAs can be classified into four subclasses, namely exonic, intronic, overlapping, and intergenic lncRNAs. According to their function, lncRNAs can be categorized as signal, decoy, sponge, guide, and scaffold molecules. It has become increasingly clear that lncRNAs are involved in tumorigenesis in many cancers. This network should serve as a guide for "navigating" through the lncRNAs research in the literature.

\section{Acknowledgment}

This work was supported by grants from the National Natural Science Foundation of China (Nos 30871189, 81171841, 81200366, 81372515, 81401901, and 81572281).

\section{Disclosure}

The authors report no conflicts of interest in this work.

\section{References}

1. Wu Y, Liu H, Shi X, Yao Y, Yang W, Song Y. The long non-coding RNA HNF1A-AS1 regulates proliferation and metastasis in lung adenocarcinoma. Oncotarget. 2015;6(11):9160-9172.

2. Chen Z, Fillmore CM, Hammerman PS, Kim CF, Wong KK. Non-smallcell lung cancers: a heterogeneous set of diseases. Nat Rev Cancer. 2014; 14(8):535-546.

3. Davidson MR, Gazdar AF, Clarke BE. The pivotal role of pathology in the management of lung cancer. J Thorac Dis. 2013;5 Suppl 5:S463-S478.

4. Langer CJ, Besse B, Gualberto A, Brambilla E, Soria JC. The evolving role of histology in the management of advanced non-small-cell lung cancer. J Clin Oncol. 2010;28(36):5311-5320.

5. Cancer Genome Atlas Research Network. Comprehensive genomic characterization of squamous cell lung cancers. Nature. 2012;489(7417): 519-525.
6. Iyer MK, Niknafs YS, Malik R, et al. The landscape of long noncoding RNAs in the human transcriptome. Nat Genet. 2015;47(3):199-208.

7. Derrien T, Johnson R, Bussotti G, et al. The GENCODE v7 catalog of human long noncoding RNAs: analysis of their gene structure, evolution, and expression. Genome Res. 2012;22(9):1775-1789.

8. Kapusta A, Kronenberg Z, Lynch VJ, et al. Transposable elements are major contributors to the origin, diversification, and regulation of vertebrate long noncoding RNAs. PLoS Genet. 2013;9(4):e1003470.

9. Johnson R, Guigo R. The RIDL hypothesis: transposable elements as functional domains of long noncoding RNAs. RNA. 2014;20(7):959-976.

10. Guttman M, Amit I, Garber M, et al. Chromatin signature reveals over a thousand highly conserved large non-coding RNAs in mammals. Nature. 2009;458(7235):223-227.

11. Diederichs S. The four dimensions of noncoding RNA conservation. Trends Genet. 2014;30(4):121-123.

12. Gutschner T, Hammerle M, Eissmann M, et al. The noncoding RNA MALAT1 is a critical regulator of the metastasis phenotype of lung cancer cells. Cancer Res. 2013;73(3):1180-1189.

13. Chu C, Qu K, Zhong FL, Artandi SE, Chang HY. Genomic maps of long noncoding RNA occupancy reveal principles of RNA-chromatin interactions. Mol Cell. 2011;44(4):667-678.

14. Shi X, Sun M, Liu H, Yao Y, Song Y. Long non-coding RNAs: a new frontier in the study of human diseases. Cancer Lett. 2013;339(2):159-166.

15. Wu L, Murat P, Matak-Vinkovic D, Murrell A, Balasubramanian S. Binding interactions between long noncoding RNA HOTAIR and PRC2 proteins. Biochemistry. 2013;52(52):9519-9527.

16. Betancur JG, Tomari Y. Cryptic RNA-binding by PRC2 components EZH2 and SUZ12. RNA Biol. 2015;12(9):959-965.

17. Khalil AM, Guttman M, Huarte M, et al. Many human large intergenic noncoding RNAs associate with chromatin-modifying complexes and affect gene expression. Proc Natl Acad Sci U S A. 2009;106(28): 11667-11672.

18. Pandey RR, Mondal T, Mohammad F, et al. Kcnq1 ot1 antisense noncoding RNA mediates lineage-specific transcriptional silencing through chromatin-level regulation. Mol Cell. 2008;32(2):232-246.

19. Wang KC, Chang HY. Molecular mechanisms of long noncoding RNAs. Mol Cell. 2011;43(6):904-914.

20. Huarte M, Guttman M, Feldser D, et al. A large intergenic noncoding RNA induced by $\mathrm{p} 53$ mediates global gene repression in the p53 response. Cell. 2010;142(3):409-419.

21. Poliseno L, Salmena L, Zhang J, Carver B, Haveman WJ, Pandolfi PP. A coding-independent function of gene and pseudogene mRNAs regulates tumour biology. Nature. 2010;465(7301):1033-1038.

22. Hu Y, Wang J, Qian J, et al. Long noncoding RNA GAPLINC regulates CD44-dependent cell invasiveness and associates with poor prognosis of gastric cancer. Cancer Res. 2014;74(23):6890-6902.

23. Wang H, Zhang X, Liu Y, et al. Downregulated miR-31 level associates with poor prognosis of gastric cancer and its restoration suppresses tumor cell malignant phenotypes by inhibiting E2F2. Oncotarget. 2016;5:36577-36589.

24. Hansen TB, Jensen TI, Clausen BH, et al. Natural RNA circles function as efficient microRNA sponges. Nature. 2013;495(7441):384-388.

25. Loewen G, Jayawickramarajah J, Zhuo Y, Shan B. Functions of lncRNA HOTAIR in lung cancer. J Hematol Oncol. 2014;7(1):90.

26. Li W, Notani D, Ma Q, et al. Functional roles of enhancer RNAs for oestrogen-dependent transcriptional activation. Nature. 2013;498(7455): 516-520.

27. Zhao J, Sun BK, Erwin JA, Song JJ, Lee JT. Polycomb proteins targeted by a short repeat RNA to the mouse X chromosome. Science. 2008; 322(5902):750-756.

28. Bao X, Wu H, Zhu X, et al. The p53-induced lincRNA-p21 derails somatic cell reprogramming by sustaining $\mathrm{H} 3 \mathrm{~K} 9 \mathrm{me} 3$ and $\mathrm{CpG}$ methylation at pluripotency gene promoters. Cell Res. 2015;25(1): 80-92.

29. Yang L, Lin C, Jin C, et al. lncRNA-dependent mechanisms of androgen-receptor-regulated gene activation programs. Nature. 2013; 500(7464):598-602. 
30. Pan Q, Shai O, Lee LJ, Frey BJ, Blencowe BJ. Deep surveying of alternative splicing complexity in the human transcriptome by highthroughput sequencing. Nat Genet. 2008;40(12):1413-1415.

31. Barash Y, Calarco JA, Gao W, et al. Deciphering the splicing code. Nature. 2010;465(7294):53-59.

32. Saint-Andre V, Batsche E, Rachez C, Muchardt C. Histone H3 lysine 9 trimethylation and HP1gamma favor inclusion of alternative exons. Nat Struct Mol Biol. 2011;18(3):337-344.

33. Gonzalez I, Munita R, Agirre E, et al. A lncRNA regulates alternative splicing via establishment of a splicing-specific chromatin signature. Nat Struct Mol Biol. 2015;22(5):370-376.

34. Tripathi V, Ellis JD, Shen Z, et al. The nuclear-retained noncoding RNA MALAT1 regulates alternative splicing by modulating SR splicing factor phosphorylation. Mol Cell. 2010;39(6):925-938.

35. Ji P, Diederichs $\mathrm{S}$, Wang W, et al. MALAT-1, a novel noncoding RNA, and thymosin beta4 predict metastasis and survival in early-stage nonsmall cell lung cancer. Oncogene. 2003;22(39):8031-8041.

36. Wilusz JE, JnBaptiste CK, Lu LY, et al. A triple helix stabilizes the $3^{\prime}$ ends of long noncoding RNAs that lack poly(A) tails. Genes Dev. 2012;26(21):2392-2407.

37. Brown JA, Valenstein ML, Yario TA, Tycowski KT, Steitz JA. Formation of triple-helical structures by the $3^{\prime}$-end sequences of MALAT1 and MENbeta noncoding RNAs. Proc Natl Acad Sci U S A. 2012;109(47): 19202-19207.

38. Friedel CC, Dolken L, Ruzsics Z, Koszinowski UH, Zimmer R. Conserved principles of mammalian transcriptional regulation revealed by RNA half-life. Nucleic Acids Res. 2009;37(17):e115.

39. Wilusz JE, Freier SM, Spector DL. 3' end processing of a long nuclearretained noncoding RNA yields a tRNA-like cytoplasmic RNA. Cell. 2008;135(5):919-932.

40. Bernstein E, Duncan EM, Masui O, Gil J, Heard E, Allis CD. Mouse polycomb proteins bind differentially to methylated histone $\mathrm{H} 3$ and RNA and are enriched in facultative heterochromatin. Mol Cell Biol. 2006;26(7):2560-2569.

41. Hutchinson JN, Ensminger AW, Clemson CM, Lynch CR, Lawrence JB, Chess A. A screen for nuclear transcripts identifies two linked noncoding RNAs associated with SC35 splicing domains. BMC Genomics. 2007;8:39.

42. Yoshimoto R, Mayeda A, Yoshida M, et al. MALAT1 long noncoding RNA in cancer. Biochimica et biophysica acta. 2016;1859(1): 192-199.

43. Gutschner T, Baas M, Diederichs S. Noncoding RNA gene silencing through genomic integration of RNA destabilizing elements using zinc finger nucleases. Genome Res. 2011;21(11):1944-1954.

44. Gutschner T, Hammerle M, Diederichs S. MALAT1 - a paradigm for long noncoding RNA function in cancer. J Mol Med (Berl). 2013;91(7): 791-801.

45. Tano K, Mizuno R, Okada T, et al. MALAT-1 enhances cell motility of lung adenocarcinoma cells by influencing the expression of motilityrelated genes. FEBS Lett. 2010;584(22):4575-4580.

46. Shen L, Chen L, Wang Y, Jiang X, Xia H, Zhuang Z. Long noncoding RNA MALAT1 promotes brain metastasis by inducing epithelial-mesenchymal transition in lung cancer. J Neurooncol. 2015; 121(1):101-108.

47. Yang F, Yi F, Han X, Du Q, Liang Z. MALAT-1 interacts with hnRNP C in cell cycle regulation. FEBS Lett. 2013;587(19):3175-3181.

48. Schmidt LH, Gorlich D, Spieker T, et al. Prognostic impact of Bcl-2 depends on tumor histology and expression of MALAT-1 lncRNA in non-small-cell lung cancer. $J$ Thorac Oncol. 2014;9(9):1294-1304.

49. Zhang J, Zhang B, Wang T, Wang H. LncRNA MALAT1 overexpression is an unfavorable prognostic factor in human cancer: evidence from a meta-analysis. Int J Clin Exp Med. 2015;8(4):5499-5505.

50. Fatica A, Bozzoni I. Long non-coding RNAs: new players in cell differentiation and development. Nat Rev Genet. 2013;15(1):7-21.

51. Somarowthu S, Legiewicz M, Chillon I, Marcia M, Liu F, Pyle AM. HOTAIR forms an intricate and modular secondary structure. Mol Cell. 2015;58(2):353-361.
52. Bhan A, Mandal SS. LncRNA HOTAIR: A master regulator of chromatin dynamics and cancer. Biochim Biophys Acta. 2015; 1856(1):151-164.

53. Wu Y, Zhang L, Zhang L, et al. Long non-coding RNA HOTAIR promotes tumor cell invasion and metastasis by recruiting EZH2 and repressing E-cadherin in oral squamous cell carcinoma. Int J Oncol. 2015; 46(6):2586-2594.

54. Tsai MC, Manor O, Wan Y, et al. Long noncoding RNA as modular scaffold of histone modification complexes. Science. 2010;329(5992): 689-693.

55. Hang H, Xing Z, Mani SKK, et al. RNA helicase DDX5 regulates PRC2/HOTAIR function in Hepatitis B Virus infection and hepatocarcinogenesis. Hepatology. 2016;1-53.

56. Chiyomaru T, Yamamura S, Fukuhara S, et al. Genistein inhibits prostate cancer cell growth by targeting miR-34a and oncogenic HOTAIR. PLoS One. 2013;8(8):e70372.

57. Yoon JH, Abdelmohsen K, Kim J, et al. Scaffold function of long non-coding RNA HOTAIR in protein ubiquitination. Nat Commun. 2013;4:2939.

58. Zhao W, An Y, Liang Y, Xie XW. Role of HOTAIR long noncoding RNA in metastatic progression of lung cancer. Eur Rev Med Pharmacol Sci. 2014;18(13):1930-1936.

59. Ono H, Motoi N, Nagano H, et al. Long noncoding RNA HOTAIR is relevant to cellular proliferation, invasiveness, and clinical relapse in small-cell lung cancer. Cancer Med. 2014;3(3):632-642.

60. Nakagawa T, Endo H, Yokoyama M, et al. Large noncoding RNA HOTAIR enhances aggressive biological behavior and is associated with short disease-free survival in human non-small cell lung cancer. Biochem Biophys Res Commun. 2013;436(2):319-324.

61. Liu XH, Lu KH, Wang KM, et al. MicroRNA-196a promotes nonsmall cell lung cancer cell proliferation and invasion through targeting HOXA5. BMC Cancer. 2012;12:348.

62. Zhuang Y, Wang X, Nguyen HT, et al. Induction of long intergenic non-coding RNA HOTAIR in lung cancer cells by type I collagen. J Hematol Oncol. 2013;6:35.

63. Liu Z, Sun M, Lu K, et al. The long noncoding RNA HOTAIR contributes to cisplatin resistance of human lung adenocarcinoma cells via downregualtion of p21 (WAF1/CIP1) expression. PLoS One. 2013;8(10):e77293.

64. Zhou C, Ye L, Jiang C, Bai J, Chi Y, Zhang H. Long noncoding RNA HOTAIR, a hypoxia-inducible factor-1alpha activated driver of malignancy, enhances hypoxic cancer cell proliferation, migration, and invasion in non-small cell lung cancer. Tumour Biol. 2015;36(12): 9179-9188.

65. Shahryari A, Jazi MS, Samaei NM, Mowla SJ. Long non-coding RNA SOX2OT: expression signature, splicing patterns, and emerging roles in pluripotency and tumorigenesis. Front Genet. 2015;6:196.

66. Hou Z, Zhao W, Zhou J, et al. A long noncoding RNA Sox2ot regulates lung cancer cell proliferation and is a prognostic indicator of poor survival. Int J Biochem Cell Biol. 2014;53:380-388.

67. Amaral PP, Neyt C, Wilkins SJ, et al. Complex architecture and regulated expression of the Sox2ot locus during vertebrate development. RNA. 2009;15(11):2013-2027.

68. Bass AJ, Watanabe $\mathrm{H}, \mathrm{Mermel} \mathrm{CH}$, et al. SOX2 is an amplified lineagesurvival oncogene in lung and esophageal squamous cell carcinomas. Nat Genet. 2009;41(11):1238-1242.

69. Pasmant E, Laurendeau I, Heron D, Vidaud M, Vidaud D, Bièche I. Characterization of a germ-line deletion, including the entire INK4/ ARF locus, in a melanoma-neural system tumor family: identification of ANRIL, an antisense noncoding RNA whose expression coclusters with ARF. Cancer Res. 2007;67(8):3963-3969.

70. Nie FQ, Sun M, Yang JS, et al. Long noncoding RNA ANRIL promotes non-small cell lung cancer cell proliferation and inhibits apoptosis by silencing KLF2 and P21 expression. Mol Cancer Ther. 2015;14(1): 268-277.

71. Fernandez-Zapico ME, Lomberk GA, Tsuji S, et al. A functional familywide screening of SP/KLF proteins identifies a subset of suppressors of KRAS-mediated cell growth. Biochem J. 2011;435(2):529-537. 
72. Zhang EB, Kong R, Yin DD, et al. Long noncoding RNA ANRIL indicates a poor prognosis of gastric cancer and promotes tumor growth by epigenetically silencing of $\mathrm{miR}-99 \mathrm{a} / \mathrm{miR}-449 \mathrm{a}$. Oncotarget. 2014;5(8):2276-2292.

73. Ren XS, Yin MH, Zhang X, et al. Tumor-suppressive microRNA-449a induces growth arrest and senescence by targeting E2F3 in human lung cancer cells. Cancer Lett. 2014;344(2):195-203.

74. Onyango P, Feinberg AP. A nucleolar protein, H19 opposite tumor suppressor (HOTS), is a tumor growth inhibitor encoded by a human imprinted H19 antisense transcript. Proc Natl Acad Sci U S A. 2011; 108(40):16759-16764

75. Matouk I, Raveh E, Ohana P, et al. The increasing complexity of the oncofetal h19 gene locus: functional dissection and therapeutic intervention. Int J Mol Sci. 2013;14(2):4298-4316.

76. Schoenherr CJ, Levorse JM, Tilghman SM. CTCF maintains differential methylation at the Igf2/H19 locus. Nat Genet. 2003;33(1):66-69.

77. Kallen AN, Zhou XB, Xu J, et al. The imprinted H19 lncRNA antagonizes let-7 microRNAs. Mol Cell. 2013;52(1):101-112.

78. Matouk IJ, Halle D, Gilon M, Hochberg A. The non-coding RNAs of the H19-IGF2 imprinted loci: a focus on biological roles and therapeutic potential in lung cancer. J Transl Med. 2015;13:113.

79. Matouk IJ, Raveh E, Abu-lail R, et al. Oncofetal H19 RNA promotes tumor metastasis. Biochim Biophys Acta. 2014;1843(7):1414-1426.

80. Matouk IJ, DeGroot N, Mezan S, et al. The H19 non-coding RNA is essential for human tumor growth. PLoS One. 2007;2(9):e845.

81. Kaplan R, Luettich K, Heguy A, Hackett NR, Harvey BG, Crystal RG. Monoallelic up-regulation of the imprinted H19 gene in airway epithelium of phenotypically normal cigarette smokers. Cancer Res. 2003; 63(7):1475-1482.

82. Luo J, Tang L, Zhang J, et al. Long non-coding RNA CARLo-5 is a negative prognostic factor and exhibits tumor pro-oncogenic activity in non-small cell lung cancer. Tumour Biol. 2014;35(11): 11541-11549.

83. Kim T, Cui R, Jeon YJ, et al. Long-range interaction and correlation between MYC enhancer and oncogenic long noncoding RNA CARLo-5. Proc Natl Acad Sci US A. 2014;111(11):4173-4178.

84. Nie FQ, Zhu Q, Xu TP, et al. Long non-coding RNA MVIH indicates a poor prognosis for non-small cell lung cancer and promotes cell proliferation and invasion. Tumour Biol. 2014;35(8):7587-7594.

85. Barsotti AM, Beckerman R, Laptenko O, Huppi K, Caplen NJ, Prives C. p53-Dependent induction of PVT1 and miR-1204. J Biol Chem. 2012;287(4):2509-2519.

86. Yang YR, Zang SZ, Zhong CL, Li YX, Zhao SS, Feng XJ. Increased expression of the lncRNA PVT1 promotes tumorigenesis in non-small cell lung cancer. Int J Clin Exp Pathol. 2014;7(10):6929-6935.

87. Gibb EA, Warren RL, Wilson GW, et al. Activation of an endogenous retrovirus-associated long non-coding RNA in human adenocarcinoma. Genome Med. 2015;7(1):22.

88. Hanahan D, Weinberg RA. Hallmarks of cancer: the next generation. Cell. 2011;144(5):646-674.

89. Lu KH, Li W, Liu XH, et al. Long non-coding RNA MEG3 inhibits NSCLC cells proliferation and induces apoptosis by affecting p53 expression. BMC Cancer. 2013;13:461.

90. Zhou Y, Zhong Y, Wang Y, et al. Activation of p53 by MEG3 noncoding RNA. J Biol Chem. 2007;282(34):24731-24742.

91. Zhang X, Rice K, Wang Y, et al. Maternally expressed gene 3 (MEG3) noncoding ribonucleic acid: isoform structure, expression, and functions. Endocrinology. 2010;151(3):939-947.

92. Khaitan D, Dinger ME, Mazar J, et al. The melanoma-upregulated long noncoding RNA SPRY4-IT1 modulates apoptosis and invasion. Cancer Res. 2011;71(11):3852-3862.

93. Xie HW, Wu QQ, Zhu B, et al. Long noncoding RNA SPRY4-IT1 is upregulated in esophageal squamous cell carcinoma and associated with poor prognosis. Tumour Biol. 2014;35(8):7743-7754.

94. Zhang HM, Yang FQ, Yan Y, Che JP, Zheng JH. High expression of long non-coding RNA SPRY4-IT1 predicts poor prognosis of clear cell renal cell carcinoma. Int J Clin Exp Pathol. 2014;7(9):5801-5809.
95. Sun M, Liu XH, Lu KH, et al. EZH2-mediated epigenetic suppression of long noncoding RNA SPRY4-IT1 promotes NSCLC cell proliferation and metastasis by affecting the epithelial-mesenchymal transition. Cell Death Dis. 2014;5:e1298.

96. Behrens C, Solis LM, Lin H, et al. EZH2 protein expression associates with the early pathogenesis, tumor progression, and prognosis of non-small cell lung carcinoma. Clin Cancer Res. 2013;19(23): 6556-6565.

97. Han L, Zhang EB, Yin DD, et al. Low expression of long noncoding RNA PANDAR predicts a poor prognosis of non-small cell lung cancer and affects cell apoptosis by regulating Bcl-2. Cell Death Dis. 2015;6:e1665.

98. Hung T, Wang Y, Lin MF, et al. Extensive and coordinated transcription of noncoding RNAs within cell-cycle promoters. Nat Genet. 2011; 43(7):621-629.

99. Hirose T, Steitz JA. Position within the host intron is critical for efficient processing of box C/D snoRNAs in mammalian cells. Proc Natl Acad Sci U S A. 2001;98(23):12914-12919.

100. Kino T, Hurt DE, Ichijo T, Nader N, Chrousos GP. Noncoding RNA gas5 is a growth arrest- and starvation-associated repressor of the glucocorticoid receptor. Sci Signal. 2010;3(107):a8.

101. Sun M, Jin FY, Xia R, et al. Decreased expression of long noncoding RNA GAS5 indicates a poor prognosis and promotes cell proliferation in gastric cancer. BMC Cancer. 2014;14:319.

102. Tu ZQ, Li RJ, Mei JZ, Li XH. Down-regulation of long non-coding RNA GAS5 is associated with the prognosis of hepatocellular carcinoma. Int J Clin Exp Pathol. 2014;7(7):4303-4309.

103. Yin D, He X, Zhang E, Kong R, De W, Zhang Z. Long noncoding RNA GAS5 affects cell proliferation and predicts a poor prognosis in patients with colorectal cancer. Med Oncol. 2014;31(11):253.

104. Shi X, Sun M, Liu H, et al. A critical role for the long non-coding RNA GAS5 in proliferation and apoptosis in non-small-cell lung cancer. Mol Carcinog. 2015;54 Suppl 1:E1-E12.

105. Yu X, Li Z. Long non-coding RNA growth arrest-specific transcript 5 in tumor biology. Oncol Lett. 2015;10(4):1953-1958.

106. Zhang Z, Zhu Z, Watabe K, et al. Negative regulation of lncRNA GAS5 by miR-21. Cell Death Differ. 2013;20(11):1558-1568.

107. Dong S, Qu X, Li W, et al. The long non-coding RNA, GAS5, enhances gefitinib-induced cell death in innate EGFR tyrosine kinase inhibitorresistant lung adenocarcinoma cells with wide-type EGFR via downregulation of the IGF-1R expression. J Hematol Oncol. 2015;8:43.

108. Selvaggi G, Novello S, Torri V, et al. Epidermal growth factor receptor overexpression correlates with a poor prognosis in completely resected non-small-cell lung cancer. Ann Oncol. 2004;15(1):28-32.

109. Young TL, Matsuda T, Cepko CL. The noncoding RNA taurine upregulated gene 1 is required for differentiation of the murine retina. Curr Biol. 2005;15(6):501-512.

110. Zhang EB, Yin DD, Sun M, et al. P53-regulated long non-coding RNA TUG1 affects cell proliferation in human non-small cell lung cancer, partly through epigenetically regulating HOXB7 expression. Cell Death Dis. 2014;5:e1243.

111. Han Y, Liu Y, Gui Y, Cai Z. Long intergenic non-coding RNA TUG1 is overexpressed in urothelial carcinoma of the bladder. J Surg Oncol. 2013;107(5):555-559.

112. Zhang Q, Geng PL, Yin P, Wang XL, Jia JP, Yao J. Down-regulation of long non-coding RNA TUG1 inhibits osteosarcoma cell proliferation and promotes apoptosis. Asian Pac J Cancer Prev. 2013;14(4): 2311-2315.

113. Wang Y, Chen W, Chen J, Pan Q, Pan J. LncRNA expression EGFR exon 19 deletions in lung adenocarcinoma ascertained by using microarray analysis. Med Oncol. 2014;31(9):137.

114. Guo Q, Zhao Y, Chen J, et al. BRAF-activated long non-coding RNA contributes to colorectal cancer migration by inducing epithelialmesenchymal transition. Oncol Lett. 2014;8(2):869-875.

115. Flockhart RJ, Webster DE, Qu K, et al. BRAFV600E remodels the melanocyte transcriptome and induces BANCR to regulate melanoma cell migration. Genome Res. 2012;22(6):1006-1014. 
116. Sun M, Liu XH, Wang KM, et al. Downregulation of BRAF activated non-coding RNA is associated with poor prognosis for non-small cell lung cancer and promotes metastasis by affecting epithelialmesenchymal transition. Mol Cancer. 2014;13:68.

117. Shi Y, Liu Y, Wang J, et al. Downregulated long noncoding RNA BANCR promotes the proliferation of colorectal cancer cells via downregulation of p21 expression. PLoS One. 2015;10(4):e122679.
118. van Kempen LCL, Coussens LM. MMP9 potentiates pulmonary metastasis formation. Cancer Cell. 2002;2(4):251-252.

119. Seano G, Chiaverina G, Gagliardi PA, et al. Endothelial podosome rosettes regulate vascular branching in tumour angiogenesis. Nat Cell Biol. 2014;16(10):931-941, 1-8.

\section{Publish your work in this journal}

OncoTargets and Therapy is an international, peer-reviewed, open access journal focusing on the pathological basis of all cancers, potential targets for therapy and treatment protocols employed to improve the management of cancer patients. The journal also focuses on the impact of management programs and new therapeutic agents and protocols on

\section{Dovepress}

patient perspectives such as quality of life, adherence and satisfaction. The manuscript management system is completely online and includes a very quick and fair peer-review system, which is all easy to use. Visit http://www.dovepress.com/testimonials.php to read real quotes from published authors.

Submit your manuscript here: http://www.dovepress.com/oncotargets-and-therapy-journal 